\title{
Barriers to the Adoption of Sustainable Construction
}

\author{
By Innocent Chigozie Osuizugbo ${ }^{1 *}$, Opeyemi Oyeyipo ${ }^{2}$, Ayodele Lahanmi ${ }^{3}$, \\ Adesoye Morakinyo ${ }^{2}$, Olusola Olaniyi ${ }^{1}$
}

\begin{abstract}
Studies have shown that adoption of sustainable construction practice would result in a substantial reduction in the greenhouse emissions from the construction industry. Evolving a sustainable development practice is an emergent concern for the construction industry in both developing and developed countries. Sustainable construction is concerned with site planning and design, community, indoor air quality, energy, materials, water, commissioning and marketability for the benefit of mankind. This requires enormous efforts from all the stakeholders in the industry. Sustainable construction efforts in the Nigerian construction industry have been ineffective as a result of a number of barriers that prevent a smooth transition to sustainable construction practice in the country. The aim of this study is to assess the potential barriers that hinder effective adoption of sustainable construction practice in the Nigerian Construction Industry, with a view to exploring how these barriers can be overcome and thereby achieving sustainable construction in the country. A cross-sectional questionnaire was adopted for the survey. Purposive sampling technique was used to elicit 105 copies of questionnaires from various construction professionals based in Lagos state, Nigeria. Data collected were analysed using frequency, percentage, mean, relative importance index and ranking. The results revealed that key barriers to sustainable construction in the Nigerian Construction Industry are poor government support for sustainable construction, lack of relevant laws and regulations to drive sustainable construction, lack of demand for sustainable construction from clients, low level of awareness of sustainable construction and fear of the cost of adopting sustainable construction. Based on the findings from this study, it was recommended that government should assume a greater role in the popularisation and application of sustainable strategy. The barriers identified and the suggestions made to minimize barriers to the adoption of sustainable construction in Nigeria should offer an enabling environment for stakeholders in construction sector to smoothly adopt sustainable construction for the benefit of humanity.
\end{abstract}

Keywords: adoption, barriers, construction industry, Nigeria, sustainable construction

\section{Introduction}

The term sustainable construction is synonymous with sustainable development. Sustainable development has been defined as the development that meets the needs of humans in the present without negotiating the capability of future generations to meet their own needs (Enshassi \& Mayer, 2005). Its concept is based on a structure which stands on three pillars, such as economic, environmental and social pillars (Aghimien, Aigbavboa, Oke \& Musenga, 2018). The term 'Sustainable development' has been extensively discussed and adopted in several aspects of life. Aimed at incorporating

| 'Department of Building Technology, College of Environmental Sciences, Bells University of Technology, Ota, Ogun State, Nigeria

${ }^{2}$ Department of Quantity Surveying, College of Environmental Sciences, Bells University of Technology, Ota, Ogun State, Nigeria

3Infrasource Construction LLC, Green Rd, Ann Arbor, MI. 48105, USA

${ }^{*}$ Corresponding Author 
economic, environmental and social factors to attain what is cost-effectively possible (Ametepey, Aigbavboab \& Ansahb, 2015). The construction industry has a lot of direct and indirect connections with different features of sustainable development (Enshassi \& Mayer, 2005). According to Davies \& Davies (2017), sustainable development has led to important changes in building construction. Sustainability in construction project provides a reasonable economic stand for the investors; encourages the conservation of the natural environment; and support the social well-being of the users (Aghimien et al. 2018). Therefore sustainable construction is a subset of sustainable development (Ametepey et al., 2015). Hence, sustainable construction is a strategy to achieve sustainable development which is one of the needs of the construction industry.

A glean from literature has reviewed that, construction industry is a sector that is unfriendly and unkind to the natural environment (Ametepey et al., 2015; Aghimien et al., 2018; Mosly, 2015; Djokoto, Dadzie \& Ohemeng-Ababio, 2014; Enshassi \& Mayer, 2005; Darko \& Chan, 2016; Onososen, Osanyin \& Adeyemo, 2019). According to Djokoto et al. (2014), construction industry exerts huge demand pressures on global natural resources in executing projects. Mosly (2015) noted that, huge amounts of natural resources are being consumed daily across the globe by the construction industry. Djokoto et al. (2014) lamented that the industry is the main consumer of non-renewable resources, a large source of waste, a polluter of water and air and a key contributor to land abandonment. According to Ametepey et al. (2015) and Enshassi \& Mayer (2005), population growth and the matching increase in consumption and the reduction in the carbon storage capacity through deforestation pose the most threat.

The degradation of the environment according to Enshassi \& Mayer (2005), is already affecting the quality of life of people around the world. This challenge is happening when developing economies like Nigeria and China are experiencing increasing construction project to cope with the high demands of a surge in population growth and growing economic activities (Onososen et al., 2019). According to Mosly (2015), globally, governments and the people are responsible for controlling this consumption and quest for efficient and innovative alternatives that potentially lead to sustainable development. Most countries are determined to implement sustainable construction practices in their various construction industries to curb the devastating environmental impacts of the construction sector (Aghimien et al., 2018; Ametepey et al., 2015).

The global concern on sustainability is progressively flourishing (Ametepey, et al., 2015). According to Ametepey et al. (2015), sustainable construction concept has been implemented mainly in developed countries. Though some developed countries have implemented sustainable construction, the challenge now is for developing countries of which Nigeria is among to follow suit. Sustainable construction practice in most developing countries across the globe has been characterized as poor (Enshassi \& Mayer, 2005; Ametepey et al. 2015). Many factors have been held responsible for this poor sustainable construction practice in these countries (Aghimien et al., 2018). These factors can be seen as barriers that prevents a smooth transition to sustainable construction practices. Several researches have been carried out to examine the barriers to implementation of sustainable construction in the world. The studies of Enhassi and Mayer (2003); Ahn, Pearce, Wang and Wang (2013), Ametepey et al. (2015), Aghimien et al. (2018) evaluated the barriers to the application of sustainable construction concepts in 
Palestine, United States, Ghanaian and Zambia respectively. There has been very few objective research on the subject matter of sustainable construction practices in the Nigerian Construction Industry.

Determining and understanding of potential barriers is hence essential if sustainable construction is to be attained within the construction sector of Nigeria. Once these barriers are known, the transition to sustainable construction will be a smooth one. It is based on this knowledge, that the study aimed at assessing the potential barriers that hinder effective adoption of sustainable construction practice in the Nigerian Construction Industry, with a view to exploring how these barriers can be overcome and thereby achieving sustainable construction in the country.

\section{Literature Review}

This section of the paper highlighted the concept of sustainable construction, effect of construction activities on the planet and barriers to sustainable construction.

\subsection{Sustainable Construction Concept}

The term sustainable construction is synonymous with sustainable development. The commonly used definition of sustainable development by the World Commission on Environment and Development (1987) is "meeting the needs of the present without compromising the ability of future generations to meet their own needs". Sustainable construction has been defined as the creation and responsible management of a healthy built environment based on the careful use of resources and environmental principles (Djokoto et al., 2014). Sustainable construction has also been defined as "an engineering construction process which is able to not only assure the safety, quality and other basic requirements but also maximize the resource conservation and minimize the negative influence on the environment to achieve goals of material saving, energy saving, land saving, water saving and environmental protection" (Hasan \& Zhang, 2016). According to Aghimien et al. (2018), sustainable construction is a method of creating a balance between social, economic and environmental factors in construction. The Canadian International Development Agency (CIDA) pointed out during a paper discussion that sustainable development should involve sustainability in five dimensions to include: social, environmental, economic, political and cultural dimensions (Enshassi \& Mayer, 2005). Sustainable construction is a strategy to attain the needs of construction industry of which sustainable development is one of the needs. According to Ametepey et al. (2015), sustainable construction has materialized as a guiding model to create a new kind of built environment that meets the present needs of humans without compromising the ability of future generations to meet their own needs. This type of construction is premised on the triple bottom line tenets of people, planet and profit (Davies \& Davies, 2017).

The desire to build a humane, equitable and caring global society has attracted global attention of researchers to focus more on sustainability studies (Ikediashi, Ogunlana, Oladokun \& Adewuyi, 2012). Several authors have reported six (6) principles for sustainable construction which include: (1) Minimization of resource consumption; (2) Maximization of resource reuse; (3) Use renewable and recyclable resources; (4) Protect 
the natural environment; (5) Create a healthy and non-toxic environment; and (6) Pursue quality in creating the built environment (Davies \& Davies, 2017; Djokoto et al., 2014). According to Davies \& Davies (2017), these principles of sustainable construction cut across the whole life span of construction, which start from planning stages to deconstruction. This concept has been introduced mostly in developed countries while it has attracted less attention in developing countries (Ametepey et al., 2015). Nigeria is not exempted in this case. According to Enshassi \& Mayer (2005), the implementation of the principles of sustainable construction can only be attained where there is an active acceptance of the concept by the project promoter and key players in the design and production team.

Sustainable construction requires designers and constructors to use construction practices that will not have unfavorable effect on long-term on the environment (Davies \& Davies, 2017). Djokoto et al. (2014) added that, more hopeful and positive response to calls for promoting sustainability in construction and design techniques exist. This construction process needs scientific management and technological progress (Hasan \& Zhang, 2016). According to Djokoto et al. (2014), the huge benefits associated with sustainable design and construction had made governments and their agencies to incorporate sustainable design and construction practices in both new and existing buildings.

\subsection{The Effect of Construction Activities on the Planet}

The construction industry is a sector that engages designers, constructors, manufacturers and suppliers of construction materials to either build or maintain a structure or built environment. According to Enshassi \& Mayer (2005), the built environment comprises one of the major supports of the economic development; its construction has important effects on resources and the living and working environment. Djokoto et al. (2014) lamented that the construction industry exerts huge demand pressures on global natural resources in executing projects. A glean from literature has reviewed that, construction industry is a sector that is unfriendly and unkind to the natural environment (Ametepey et al., 2015; Aghimien et al., 2018; Mosly, 2015; Djokoto et al., 2014; Enshassi \& Mayer, 2005; Darko \& Chan, 2016; Onososen et al., 2019). Scholars and scientists are increasingly aware of the fact that the earth's resources are being excessively consumed and this will likely erode the earth's support system (Aghimien et al., 2018).

The construction of buildings results in the extensive consumption of resources and materials which often leads to substantial irreversible effects upon ecosystem and landscape, whilst meeting economic and social needs for shelter and investment (Enshassi \& Mayer, 2005). According to Djokoto et al. (2014), the industry is the main consumer of non-renewable resources, a large source of waste, a polluter of water and air and a key contributor to land abandonment. Cement production contributes immensely to the emission of carbon dioxide into the environment (for instance, for every ton of cement produced, approximately a ton of CO2 is released into the atmosphere) (Djokoto et al., 2014). According to Ametepey et al. (2015) and Enshassi \& Mayer (2005), population growth and the matching increase in consumption and the reduction in the carbon storage capacity through deforestation pose the most threat. In developing 
countries, the need for sustainable construction adoption will become more important with time, because it is expected that by $203080 \%$ of developing countries' populations will be living in urban areas (Mosly, 2015). Nigeria is not left out in this phenomenon.

It is not surprising that the construction sector has been discovered to be directly responsible for excessive consumption of energy, biodiversity loss, waste generation and pollution (Onososen et al., 2019). These devastating environmental effects caused by construction industry have raised public awareness of the need for sustainable construction practices (Darko \& Chan, 2016). According to Enshassi \& Mayer (2005), sustainable construction is an approach the construction industry uses in attaining sustainable development on the various environmental, socio-economic and cultural facets. Sustainable construction aims at minimizing the use of energy and emissions that are harmful for environment and human health (Enshassi \& Mayer, 2005). Ahn et al. (2013) noted that, sustainability in the built environment is becoming a strong force in the construction industry to achieve environmental and social benefits and to reduce negative effects on the environment.

\subsection{Barriers to Sustainable Construction}

A barrier is refers to something that obstruct or hinders an operation. Barriers can be seen as situations and characteristics that hold back actions or obstruct progress towards attaining particular objectives (Vandierendonck, Liefooghe \& Verbruggen, 2010). It prevents transition from a particular state to another (in this case transitioning to sustainable construction). Barriers are often present in construction works and can obstruct the success of construction project. In other words barriers are part of development. Ayarkwa, Acheampong, Wiafe \& Boateng (2017) noted that, barriers attract negative impact on development and can be external or internal factors.

In spite of the huge benefits attributed to sustainable construction practice, its adoption and implementation is being confronted by a number of barriers. Though several steps have been taken by the developed countries to fully practice sustainable construction, barriers still exist (Djokoto et al., 2014). Sustainable construction practice in most developing countries across the globe has been characterized as poor (Enshassi \& Mayer, 2005; Ametepey et al. 2015). Many factors have been held responsible for this poor sustainable construction practice in these countries (Aghimien et al., 2018). These factors can be seen as barriers that prevents a smooth transition to sustainable construction practices. According to Darko \& Chan (2016), barriers to sustainable construction adoption will continue to be of interest to future researchers, because it is significant to identify barriers to sustainable construction in particular regions so as to develop suitable strategies in overcoming those barriers.

Studies from developed and developing countries have identified barriers to the adoption of sustainable construction practice. Ahn et al. (2013) examined the barriers of sustainable design and construction of sustainable building in United States. Similarly, embarked is the study to assess barriers to successful implementation of sustainable construction in the Ghanaian construction industry. Table 1 summarises barriers to sustainable construction identified by authors in different countries. 
Table 1: Barriers to sustainable construction identified by researchers in different countries

\section{No Barriers to Sustainable Construction}

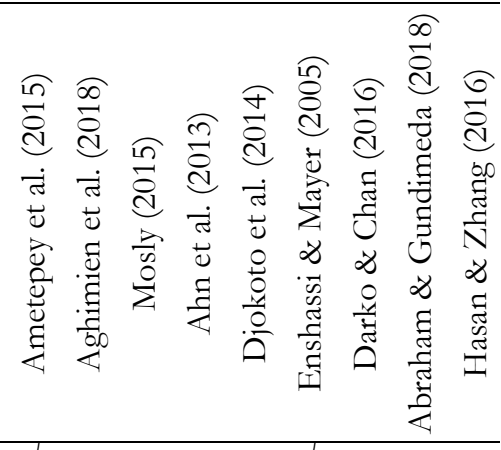

1 Cultural change resistance

2 Poor government support for sustainable construction

3 Fear of the cost of adopting sustainable construction/Fear of higher investment costs

4 Lack of professional knowledge

5 Lack of relevant laws and regulations to drive sustainable construction

6 No local green certification available

7 Lack of financial incentives

8 Lack of skilled personnel

9 Long pay back periods from sustainable practices

10 Tendency to maintain current practices

11 Lack of demand for sustainable construction from clients

12 Lack of strategy to promote sustainable construction

13 Higher initial cost

14 Low level of awareness of sustainable construction

15 Lack of knowledge about the concepts of sustainability

16 Lack of training among engineers and professionals who are involved in the construction process

17 Lack of culture on sustainable concepts

18 Inadequate institutional structures at the local level

19 A reluctant by all parties involved in construction

process to try new ideas owing to the risk factor

20 Lack of labeling

21 Weak enforcement of building codes

\section{Methodology}

This research adopted field survey method to reveal the barriers to sustainable construction in the Nigerian construction industry. To identify potential barriers to the adoption of sustainable construction in the Nigerian construction industry, a careful review of the literature was conducted. Twenty-One (21) barriers were identified (Ametepey et al., 2015; Aghimien et al., 2018; Mosly, 2015; Ahn et al., 2013; Djokoto et al., 2014; Enshassi \& Mayer, 2005; Darko \& Chan, 2016; Abraham \& Gundimeda, 2018; 
Hasan \& Zhang, 2016). In view of the fact that the barriers collated from the comprehensive literature review had been adequately investigated and used in similar studies in other countries, they were used as basis for the present study. The list of the barriers to sustainable construction was used to design a questionnaire survey which serve as the research instrument to achieve the aim of the study. The questionnaire survey was used to elicit factors that causes barrier to sustainable construction in the construction industry of Nigeria from key stakeholders in the industry. Key stakeholders particularly architects, builders, quantity surveyor and civil/structural engineers that are registered with respective professional institutions in Nigeria and main contractors and clients were approached to participate in this study. Pilot study was done on the instrument to reveal the comprehensiveness and accuracy of the research instrument before administering it to the respondents. The questionnaire used in this study was in two sections. The section one sought to investigate the background information of the participants, whereas, section two assessed the potential barriers to the adoption of sustainable construction in the Nigerian Construction Industry. The reliability of multiple Likert scale questions was measured using Cronbach's alpha. The Cronbach's alpha $(\alpha)$ value obtained using SPSS 21 was 0.89, indicating a high level of internal consistency for the scale.

This research was done in Lagos state. The choice of Lagos state was because the state has a high volume of construction works as well as huge concentration of contractors of different sizes and categories. Also Lagos state is economically an important state in Nigeria. Snowball sampling method was utilized. The method is very helpful in approaching population that is not readily available (Alvi, 2016). The participants were asked to rate the extent to which each of the barrier affects sustainable construction using a 5-point Likert scale.

Data obtained were analysed using frequency, percentage, mean, relative importance index and ranking. The relative importance index (RII) was used to rank barriers to adoption of sustainable construction in Nigerian construction industry. The RII was computed in Mbamali and Okotie (2012) as:

RII $=\frac{\sum \mathrm{fx}}{\sum \mathrm{f}} \cdot \frac{1}{\mathrm{k}}=\frac{\overline{\mathrm{x}}}{\mathrm{k}}=$ equation (1)

Where

Mean $=\bar{x}=\frac{\sum \mathrm{fx}}{\sum \mathrm{f}}$

$\mathrm{x}=$ weights given by each participant in a range of 1 to 5 on the Likert scale $(1=$ strongly disagree, $2=$ disagree, $3=$ neutral, $4=$ agree and $5=$ strongly agree). $\mathrm{f}=$ Frequency of respondents' choice of each point on the scale $\mathrm{x}, \mathrm{k}=$ Maximum point on the Likert's scale (in this case, $\mathrm{k}=5$ ). The RII computed for all barrier factors were ranked in their order of size.

\section{Results and Discussion}

Out of the 117 questionnaires distributed, 72 were adequately completed and returned representing a response rate of $61 \%$ and was used in the analysis. Under the participant's background information, information sought was professional background, 
professional membership status, highest academic qualification and years of working experience in construction industry. Results obtained revealed that 23 participants representing $32 \%$ of the sample size were civil/structural engineers with 14 participants being builders, 13 were architects, 9 were quantity surveyors, 8 were main contractors and 5 were clients. The professional membership of the respondents ranges from corporate membership to fellows. Among the corporate membership, Nigerian Society of Engineers (NSE) has the highest percentage of $32 \%$, while 7 out of 72 participants were fellows from NSE constitute 2, Nigerian Institute Architects (NIA) constitute 1, whereas Nigerian Institute of Building (NIOB) constitute 4 numbers. The professional membership records show that the participants are qualified for the survey. Also, $46 \%$ of the participants are M.Sc. holders followed by B.Tech./B.Sc. with $29 \%$. Furthermore, $82 \%$ of the respondents had been practicing in the construction industry from 11 years to more than 31 years. This reveals that the participants' capability to participate in the study was satisfactory.

\subsection{Barriers to Adoption of Sustainable Construction}

The barriers identified from literature and confirmed by stakeholders of the construction industry of Nigeria were ranked according to their Relative Importance Index (RII).

Table 2: Barriers to adoption of sustainable construction in Nigerian construction industry

\begin{tabular}{|c|c|c|c|c|c|c|c|c|c|}
\hline \multirow[t]{2}{*}{ S/No } & \multirow[t]{2}{*}{$\begin{array}{l}\text { Barriers to Adoption of Sustainable } \\
\text { Construction }\end{array}$} & \multicolumn{5}{|c|}{$\begin{array}{c}\text { Weighting } \\
\text { (x)/Response } \\
\text { Frequency (f) }\end{array}$} & \multirow[t]{2}{*}{$\Sigma \mathrm{f} \bar{x}$} & \multirow[t]{2}{*}{ RII } & \multirow[t]{2}{*}{ Rank } \\
\hline & & 1 & 2 & 3 & 4 & 5 & & & \\
\hline 1 & $\begin{array}{l}\text { Poor government support for sustainable } \\
\text { construction }\end{array}$ & 2 & 7 & 4 & 26 & 33 & 724.07 & 0.81 & 1st \\
\hline 2 & $\begin{array}{l}\text { Lack of relevant laws and regulations to } \\
\text { drive sustainable construction }\end{array}$ & 5 & 6 & 5 & 27 & 29 & 723.96 & 0.79 & 2nd \\
\hline 3 & $\begin{array}{l}\text { Lack of demand for sustainable } \\
\text { construction from clients }\end{array}$ & 5 & 7 & 11 & 24 & 25 & 723.79 & 0.76 & 3 rd \\
\hline 4 & $\begin{array}{l}\text { Low level of awareness of sustainable } \\
\text { construction }\end{array}$ & 5 & 7 & 13 & 22 & 25 & 723.76 & 0.75 & 4th \\
\hline 5 & $\begin{array}{l}\text { Fear of the cost of adopting sustainable } \\
\text { construction/Fear of higher investment } \\
\text { costs }\end{array}$ & 3 & 9 & 18 & 20 & 22 & 723.68 & 0.74 & 5th \\
\hline 6 & No local green certification available & 3 & 5 & 25 & 22 & 17 & 723.63 & 0.73 & 6th \\
\hline 7 & Weak enforcement of building codes & 3 & 4 & 26 & 22 & 17 & 723.64 & 0.73 & 6th \\
\hline 8 & $\begin{array}{l}\text { A reluctant by all parties involved in } \\
\text { construction process to try new ideas owing } \\
\text { to the risk factor }\end{array}$ & 3 & 5 & 28 & 20 & 16 & 723.57 & 0.71 & 8th \\
\hline 9 & Higher initial cost & 3 & 5 & 27 & 20 & 17 & 723.53 & 0.71 & 8th \\
\hline 10 & $\begin{array}{l}\text { Lack of knowledge about the concepts of } \\
\text { sustainability }\end{array}$ & 3 & 6 & 29 & 19 & 15 & 723.51 & 0.70 & 10th \\
\hline
\end{tabular}




\begin{tabular}{|c|c|c|c|c|c|c|c|c|c|}
\hline \multirow[t]{2}{*}{ S/No } & \multirow[t]{2}{*}{$\begin{array}{l}\text { Barriers to Adoption of Sustainable } \\
\text { Construction }\end{array}$} & \multicolumn{5}{|c|}{$\begin{array}{l}\text { Weighting } \\
\text { (x)/Response } \\
\text { Frequency (f) }\end{array}$} & \multirow[t]{2}{*}{$\Sigma f$} & \multirow[t]{2}{*}{ RII } & \multirow[t]{2}{*}{ Rank } \\
\hline & & 1 & 2 & 3 & 4 & 5 & & & \\
\hline 11 & Lack of financial incentives & 5 & 6 & 27 & 19 & 15 & 723.46 & 0.69 & 11th \\
\hline 12 & $\begin{array}{l}\text { Lack of strategy to promote sustainable } \\
\text { construction }\end{array}$ & 4 & 7 & 28 & 19 & 14 & 723.44 & 0.69 & 11 th \\
\hline 13 & Lack of skilled personnel & 4 & 7 & 30 & 17 & 14 & $72 \quad 3.42$ & 0.68 & 13th \\
\hline 14 & Lack of culture on sustainable concepts & 7 & 9 & 27 & 17 & 12 & 723.25 & 0.65 & 14 th \\
\hline 15 & Cultural change resistance & 13 & 9 & 15 & 20 & 15 & 723.21 & 0.64 & 15th \\
\hline 16 & Tendency to maintain current practices & 8 & 27 & 9 & 13 & 15 & 723.00 & 0.60 & 16th \\
\hline 17 & $\begin{array}{l}\text { Long pay back periods from sustainable } \\
\text { practices }\end{array}$ & 11 & 23 & 12 & 14 & 12 & 722.90 & 0.58 & 17 th \\
\hline 18 & Lack of labeling & 11 & 23 & 12 & 14 & 12 & 722.90 & 0.58 & 17 th \\
\hline 19 & $\begin{array}{l}\text { Lack of training among engineers and } \\
\text { professionals who are involved in the } \\
\text { construction process }\end{array}$ & 13 & 25 & 10 & 13 & 11 & 722.78 & 0.56 & 19th \\
\hline 20 & $\begin{array}{l}\text { Inadequate institutional structures at the } \\
\text { local level }\end{array}$ & 13 & 23 & 12 & 16 & 8 & 722.76 & 0.55 & 20th \\
\hline 21 & Lack of professional knowledge & 21 & 16 & 8 & 16 & 11 & 722.72 & 0.54 & $21 \mathrm{st}$ \\
\hline
\end{tabular}

$1=$ strongly disagree, $2=$ disagree, $3=$ neutral, $4=$ agree and $5=$ strongly agree, $\mathrm{x}=$ mēan, $\mathrm{f}=$ frequency

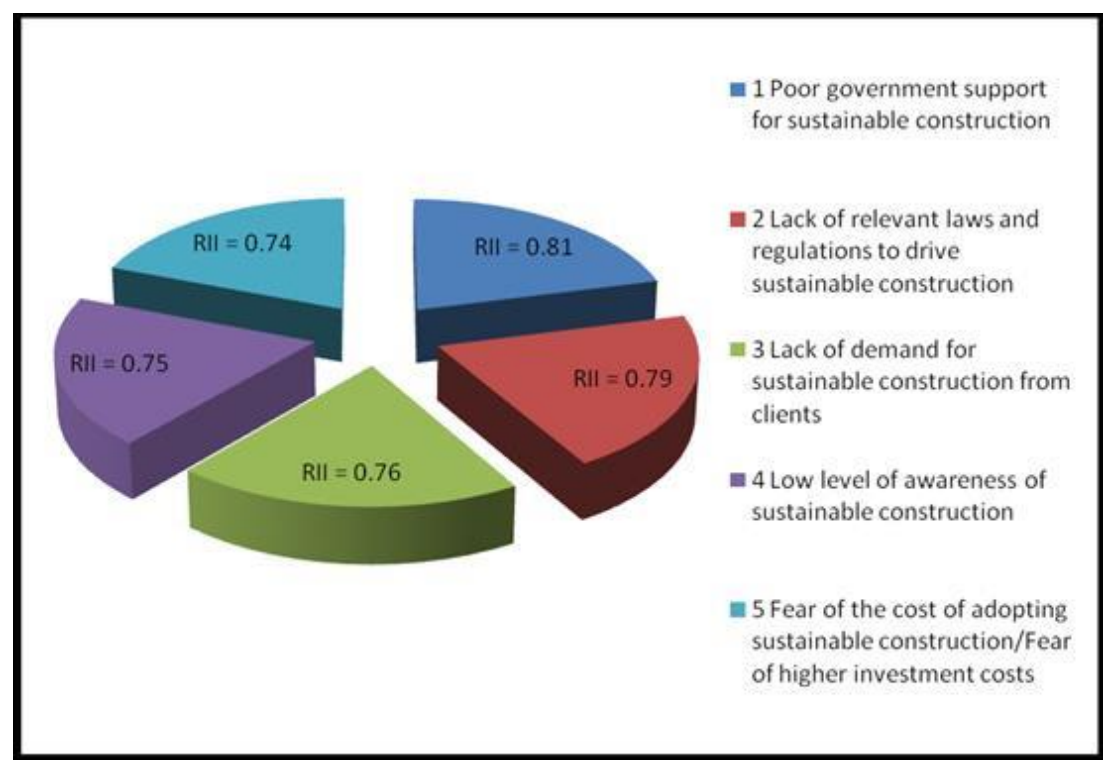

Figure 1. Top five ranked barriers to the adoption of sustainable construction in Nigerian construction industry

Potential barriers identified by the survey participants have been revealed and expressed in Table 2 and Figure 1. Results from the empirical analysis shown that the five major barriers to the adoption of sustainable construction in Nigeria are poor government support for sustainable construction $(\mathrm{RII}=0.81)$, lack of relevant laws and regulations to 
drive sustainable construction $(\mathrm{RII}=0.79)$, lack of demand for sustainable construction from clients $(\mathrm{RII}=0.76)$, low level of awareness of sustainable construction (RII = 0.75 ), and fear of the cost of adopting sustainable construction/fear of higher investment costs $(\mathrm{RII}=0.74)$. However, lack of training among engineers and professionals who are involved in the construction process $(\mathrm{RII}=0.56)$, inadequate institutional structures at the local level $(\mathrm{RII}=0.55)$ and lack of professional knowledge $(\mathrm{RII}=0.54)$ among others are the least in ranking with respect to the barriers that affect the adoption of sustainable construction in Nigeria 19th, 20th and 21st respectively as shown in Table 2. Government should be a major player in ensuring that sustainable construction is adopted in the construction industry. The effect of poor government support on the adoption of sustainable construction in Nigeria corroborates with the findings from literature (Ametepey et al., 2015; Aghimien et al., 2018; Mosly, 2015; Djokoto et al., 2014) in different countries. Secondly, the effect of Lack of relevant laws and regulations to drive sustainable construction on the adoption of sustainable construction in Nigeria confirms the findings from literature (Enshassi \& Mayer, 2005; Darko \& Chan, 2016; Abraham \& Gundimeda, 2018; Ametepey et al., 2015; Aghimien et al., 2018; Mosly, 2015) in different countries. According to Djokoto et al. (2014), governments can smooth the progress of sustainable construction by several instruments. Government plays a major role such as regulation enforcement, revision of existing policies and legislation, incentives, introduction of building codes and other fiscal instruments to lead the adoption of sustainable construction (Aghimien et al., 2018). Ametepey et al. (2015) lamented that sustainable construction cannot be productively applied without the commitment of government. Obviously, for a country such as Nigeria, the need to have a government prepared to lead in the sustainable construction practice is essential. The finding shows that the poor government support is the greatest barrier to the adoption of sustainable construction practices. And poor support by government will hinder the adoption of sustainable construction. Lack of relevant laws and regulations to drive sustainable construction was found to be the most second barrier to sustainable construction. According to Djokoto et al. (2014), laws and regulations should be replaced with implementing new ones to support sustainable development. Onososen et al. (2019) noted that, government efforts in fighting the threat caused by construction industry must be done in an economically supportive way, socially responsible and environmentally friendly.

The effect of Lack of demand for sustainable construction from clients on the adoption of sustainable construction in Nigeria corroborates with the findings from literature (Djokoto et al., 2014; Enshassi \& Mayer, 2005; Darko \& Chan, 2016) in different countries. Generally, increase in supply is usually as a result of increase in demand. Client's demand is key to the growth of sustainable construction and is directly associated to education and training in the search for adoption of sustainable construction practices (Oke, Aghimien, Aigbavboa \& Musengaa, 2019). Lack of demand for sustainable construction from clients has been known as a commonly recognized barrier (Ametepey et al., 2015). Djokoto et al. (2014) noted that most clients are not convinced on the need to demand for sustainable construction. There is need for highlight on the benefits of sustainable construction among construction clients and public. 
Effect of Low level of awareness of sustainable construction on the adoption of sustainable construction in Nigeria corroborates with the findings from literature (Djokoto et al., 2014; Enshassi \& Mayer, 2005) in different countries. The result also supports the findings of Oke et al. (2019). Level of awareness of sustainable construction by public plays a vital role in the adoption of sustainable construction (Davies \& Davies, 2017). According to Oke et al. (2019), the adoption of sustainable construction is a process that begins with awareness and then interest. Close observations in Lagos state Nigeria, reveal how some designs and construction methods are considered unsustainable, thereby encouraging high energy demand, pollution of water and air, emission of carbon dioxide and use of non-renewable materials. This signifies low level of awareness of sustainable construction. Therefore, sustainable construction practice can be held back by lack of understanding or ignorance on the subject of sustainability (Djokoto et al., 2014).

The effect of Fear of the cost of adopting sustainable construction/Fear of higher investment costs on the adoption of sustainable construction in Nigeria confirms the results from literature (Ametepey et al., 2015; Aghimien et al., 2018; Ahn et al., 2013; Djokoto et al., 2014; Enshassi \& Mayer, 2005; Darko \& Chan, 2016; Abraham \& Gundimeda, 2018; Hasan \& Zhang, 2016) in different countries. Cost is the major barriers in supporting sustainable construction process (Djokoto et al., 2014). These perceived higher costs of sustainable construction resulted in the increase of the consultant's fees and indirectly from the unfamiliarity of the design team and contractors with sustainable construction methods (Ametepey et al., 2015). Though sustainable construction costs is higher on average, the difference is not statistically significant than conventional buildings (Djokoto et al., 2014). Ametepey et al. (2015) noted that, sustainable construction practices are projected to increase initial capital cost within the range of 1 to $25 \%$ and is compensated by humongous savings in the operational costs and user comfort.

\section{Conclusion and Recommendations}

This paper aimed to identify potential barriers to the adoption of sustainable construction in the Nigerian Construction Industry. The study reviewed literature on sustainable construction. It was revealed that, developed countries are leading in terms of sustainable construction practice whereas in most developing countries sustainable construction practices are characterized as poor. The research also revealed that sustainable construction is demanding and requires team work of stakeholders in the construction sector for a smooth transition to the adoption of sustainable construction. The study identified 21 potential barriers to sustainable construction in both developed and developing countries. Consequently, this paper identified five (5) major barriers to sustainable construction in Nigeria as poor government support for sustainable construction, lack of relevant laws and regulations to drive sustainable construction, lack of demand for sustainable construction from clients, low level of awareness of sustainable construction and fear of the cost of adopting sustainable construction/fear of higher investment costs. However, lack of training among engineers and professionals who are involved in the construction process, inadequate institutional structures at the 
local level and lack of professional knowledge among others are the least with respect to the barriers that affect the adoption of sustainable construction in Nigeria.

To ensure the smooth transition to sustainable construction, stakeholders in the industry need to explore and adopt sustainable concepts especially at project design stages. Greater effort should be made to train and educate professionals in built environment and building owners about sustainable construction. Local guidelines and enforcement should be established that are consistent with the objectives and principles of the sustainable construction industry. Government should assume a greater role in the popularisation and application of sustainable strategy. The barriers identified and the suggestions made to minimize barriers to the adoption of sustainable construction in Nigeria should offer an enabling environment for stakeholders in construction sector to smoothly adopt sustainable construction for the benefit of humanity.

\section{References}

Abraham, P. S. \& Gundimeda, H., (2018). 'Greening' the Buildings - An Analysis of Barriers to Adoption in India. Cities and the Environment (CATE), Article 10, 10(1), 1-20.

Aghimien, D., Aigbavboa, C., Oke, A. \& Musenga, C., (2018). Barriers to Sustainable Construction Practices in the Zambian Construction Industry. Proceedings of the International Conference on Industrial Engineering and Operations Management Paris, France, July 26-27, 2018. 2383-2392. [Online] Available at: http://www.ieomsociety.org/paris2018/papers/445.pdf [Accessed: 11 November 2019].

Ahn, Y.H., Pearce, A. R., Wang, Y. \& Wang, G., (2013). Drivers and Barriers of Sustainable Design and Construction: The Perception of Green Building Experience. International Journal of Sustainable Building Technology and Urban Development, 4(1), 35-45, DOI: 10.1080/2093761X.2012.759887

Alvi, M. H. (2016). A Manual for Selecting Sampling Techniques in Research. Available at: https://mpra.ub.uni-muenchen.de/70218/

Ametepey, O., Aigbavboab, C. \& Ansahb, K., (2015). Barriers to Successful Implementation of Sustainable Construction in the Ghanaian Construction Industry. 6th International Conference on Applied Human Factors and Ergonomics (AHFE 2015) and the Affiliated Conferences, AHFE 2015. Procedia Manufacturing 3(2015), $1682-1689$.

Ayarkwa, J., Acheampong, A., Wiafe, F. \& Boateng, B. E., (2017). Factors Affecting the Implementation of Sustainable Construction in Ghana: The Architect's Perspective. 6th International Conference on Infrastructure Development in Africa (ICIDA), 12-14 April 2017, Knust, Kumasi, Ghana, 377386.

Darko, A. \& Chan, A. P. C., (2016). Review of Barriers to Green Building Adoption. Sustainable Development, DOI: $10.1002 /$ sd.1651

Davies, O. O. A. \& Davies, I. O. E., (2017). Barriers to Implementation of Sustainable Construction Techniques. MAYFEB Journal of Environmental Science, 2(2017), 1-9.

Djokoto, S. D., Dadzie, J. \& Ohemeng-Ababio, E., (2014). Barriers to Sustainable Construction in the Ghanaian Construction Industry: Consultants Perspectives. Journal of Sustainable Development, 7(1), 134-143. DOI:10.5539/jsd.v7n1p134

Enshassi, A. \& Mayer, P. E., (2005). Barriers to the Application of Sustainable Construction Concepts in Palestine. The 2005 World Sustainable Building Conference, Tokyo, 27-29 September 2005 (SB05Tokyo), 4624-4628. [Online] Available at: http://www.irbnet.de/daten/iconda/CIB3864.pdf [Accessed: 11 November 2019].

Hasan, M. S. M. S. \& Zhang, R., (2016). Critical Barriers and Challenges in Implementation of Green Construction in China. International Journal of Current Engineering and Technology, 6(2), 435-445.

Ikediashi, D. I., Ogunlana, S. O., Oladokun, M. G. \& Adewuyi, T., (2012). Assessing the Level of Commitment and Barriers to Sustainable Facilities Management Practice: A Case of Nigeria. International Journal of Sustainable Built Environment, 1(2102), 167-176.

Mbamali, I. and Okotie, A. J. (2012). An Assessment of the Threats and Opportunities of Globalization on Building Practice in Nigeria. American International Journal of Contemporary Research, 2(4), 143-150. 
Mosly, I., (2015). Barriers to the Diffusion and Adoption of Green Buildings in Saudi Arabia. Journal of Management and Sustainability, 5(4), 104-114.

Oke, A., Aghimien, D., Aigbavboa, C. \& Musengaa, C. (2019). Drivers of Sustainable Construction Practices in the Zambian Construction Industry. Energy Procedia 158 (2019), 10th International Conference on Applied Energy (ICAE2018), August 22 - 25, 2018, Hong Kong, China.

Onososen, A. O., Osanyin, O. \& Adeyemo, M. O. (2019). Drivers and Barriers to the Implementation of Green Building Development. PM World Journal, 8(9), 1-15.

Vandierendonck, A., Liefooghe, B. \& Verbruggen, F., (2010). Task Switching: Interplay of Reconfiguration and Interference Control. Psychological bulletin, 136(4), 601.

World Commission on Environment and Development (WCED), (1987). The Brundtland Commission Report - Our Common Future. Oxford: Oxford University Press. 